\title{
CASPIAN TERN BANDED AT DORE LAKE, SK: THIRD OLDEST AT 28 YEARS, 7 MONTHS
}

C. STUART HOUSTON, 863 University Drive, Saskatoon, SK S7N 0J8, PHILIP D. MCLOUGHLIN, Department of Biology, 112 Science Place, University of Saskatchewan, Saskatoon SK S7N 5E2, and JAMES PINSON LUDWIG, 607 Canard, Port Williams, NS BOP 1 TO.

At 4:00 a.m. on 8 July 1978, A. B. (Tony) German, Mary Houston and the senior author motored to Dore Lake, SK. On Rock Island $\left(54^{\circ} 43^{\prime} \mathrm{N}\right.$ and $107^{\circ}$ $9^{\prime} \mathrm{W}$ ) at dawn the following morning, we banded 171 Caspian Terns on the flat grassy plateau in the center of the island, as well as 151 flightless California Gulls and 5 Herring Gulls. We flushed three Lesser Scaup from nests with 11, 9, and 9 eggs; two of the scaup nests were only $2.2 \mathrm{~m}$ apart. We did not disturb the Double-crested Cormorants and American White Pelicans on the rocky point.

This 1978 trip was our fourth to Dore Lake. The 321 Caspian Terns banded between 1964 and 1978 yielded 7 recoveries (Table 1 ). Two terns banded in 1978 were recovered: one in January 1979 at Pecan Island, Louisiana; the second on 11 January 2007, near Kenner, Louisiana. With a birth date of about 1 June 1978, the latter was 28 years, 7 months old (28.6 years). The banded Caspian Tern had been struck by the wing of a Boeing 737 (a group of 16 gulls was involved with the tern in the air strike while the plane was taxiing) and the tern died shortly afterwards. Mike Scarlato had actually watched the tern die (Mike Scarlato, April and June 2007, pers. comm.).

I fully expected this tern to set a new longevity record. I went to the banding longevity website where the oldest terns were as follows: Roseate Tern 21 years, 0 months; Royal Tern - 24 years, 3 months; Sandwich Tern - 22 years, 1 month; Common Tern - 25 years, 0 months. ${ }^{5}$ The oldest Caspian Tern was listed at 29 years, 6 months, so perhaps the Dore Lake tern was second oldest? I next obtained from the Canadian Wildlife Service Ottawa banding office a printout of all 3475 Caspian Tern recoveries and encounters.

What an interesting data set this was! Long-term studies of Caspian Terns, chiefly by the Ludwig family on islands in Lake Michigan, have involved recaptures of breeding birds on their nests, these recaptures peaking among terns that were four to eight years of age. ${ }^{1,2}$ On 747 occasions, an adult tern had been recaptured on its nest, (using either a cannon net or nylon nooses around the rim of the nest, ${ }^{3}$ ) within the same ten-minute block of latitude and longitude in which it had been banded as a nestling, and on 724 occasions, the recapture was in a different 10-minute block from where it had been banded. It was common for recaptured terns to require their bands to be replaced because size 5 aluminum bands on terns lose, on average, $3 \%$ of their weight per year and because the band falls off when 50 to $65 \%$ of the metal has worn away. ${ }^{4}$ Among the recaptured birds, 625 had received replacement bands: 530 , 


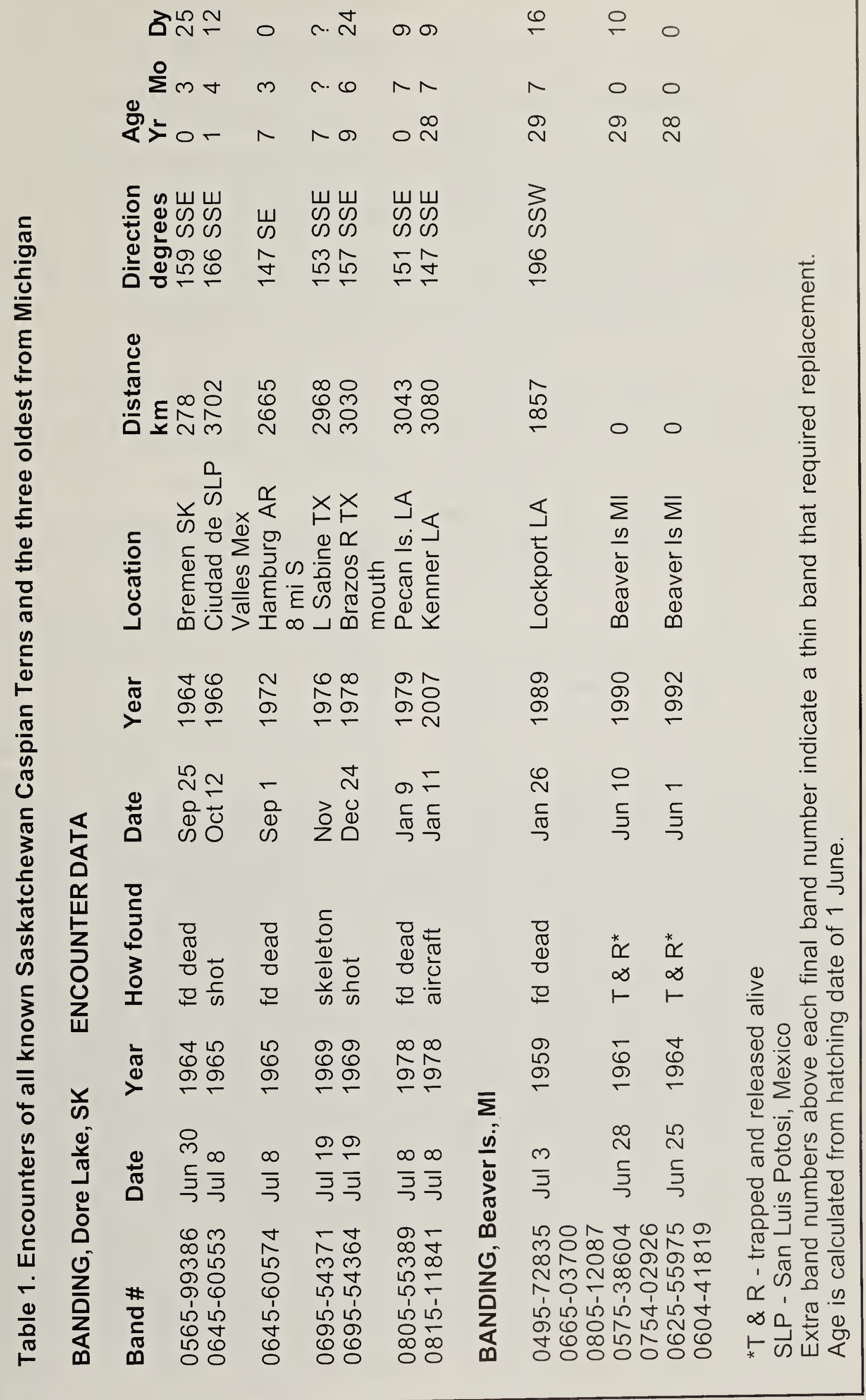


once; 73 , twice, and 22 , three times, for a total of 742 replacement bands on 625 terns.

Among the 3,475 recoveries and encounters, the three oldest were each banded on the Beaver Islands in Lake Michigan at $45^{\circ} 40^{\prime} \mathrm{N}, 85^{\circ} 10^{\prime} \mathrm{W}$ by F.E. Ludwig or his son, J.P. Ludwig (Table 1 ). Assuming that each tern was hatched about 1 June, the oldest, after being recaptured on its nest at 7,8 and 18 years and having its band replaced twice, was found dead at Lockport, Louisiana, at 29 years, 7 months and 16 days (29.67 years). The second oldest was recaptured at 29 years and 10 days of age (29.08 years) and its band had been replaced once. The third oldest, recaptured at its nest site on the Beaver Islands, was precisely 28 years old and also had had one band replacement.

The recent Saskatchewan tern that met its fate at the Kenner, Louisiana airport was thereby the third oldest Caspian Tern known from North American banding. It was all the more exceptional because it was still carrying its original band. Mike Scarlato mailed this band to Saskatoon. The band number was clearly visible even though the band was of irregular thickness and light in weight. The band varied from 0.71 to $0.84 \mathrm{~mm}$ in thickness, and weighed only 0.4197 grams. The reference band of the same size 5 was $1.07 \mathrm{~mm}$ thick and weighed 0.7188 grams. Thus the 28-year-old band had lost $41.6 \%$ of its weight, and the Caspian Tern is the oldest on record carrying its original band.

1. HOUSTON, C.S. 2006. In Memoriam: Frederick E. Ludwig, 1909-2002. Waterbirds 29:405.

2. LUDWIG, F.E. 1942. Migration of Caspian Terns banded in the Great Lakes area. Bird-Banding 13:19.

3. LUDWIG, J.P. 1980. Present status of the Caspian Tern population of the Great Lakes. Michigan Academician 12: 69-77.

4. LUDWIG, J.P. 1981. Band wear and band loss in the Great Lakes Caspian Tern population and a generalized model of band loss. Colonial Waterbirds 4:174-186.

5. PATUXENT WILDLIFE RESEARCH CENTER, Longevity Records (current through 2006), Http:/ /www.pwrc.usgs.gov/bbl/homepage/longvist.htm

"Thousands and thousands of birds, both great and small, stretch in endless wisps away to the south....High above all were the eagles. Sailing on mighty pinions, they soared in immense circles. What did distance mean to them? Some were weaving their circles so high that they were barely visible. Below them, but still high above the earth, flew the geese.

These wary birds flew in regular gaggles, beating their powerful wings, sending their honk honk ringing through the air. At a lower level bustled the duck...And all these birds were speeding southwards, a magnificent sight." V. K. Arseniev, Dersu the Trapper, p. 30-31. 